\title{
PENGARUH MOTIVASI, PELATIHAN DAN PENGEMBANGAN TERHADAP KINERJA KARYAWAN PADA LEVEL OPERATOR DI PT. SUBANG AUTOCOMP INDONESIA
}

\author{
Liandy Lumban Tobing, Edi Suswardji Nugroho dan Solehudin \\ Universitas Singaperbangsa Karawang, Jawa Barat, Indonesia \\ Email: 1910632020023@student.unsika.ac.id, edisus.nugroho@fe.unsika.ac.id dan \\ solehudin@unsika.ac.id
}

\begin{abstract}
The purpose of this study was to analyze the influence of motivation, training and development on employee performance at the operator level of PT. Subang Autocomp Indonesia. This type of research is causal associative. The population of this study were all employees at the operator level at PT. Subang Autocomp Indonesia totaling 111 employees and as many as 87 people were sampled. This research data collection method is a questionnaire, interview and documentation. The data analysis method used descriptive analysis and multiple linear regression. The results of this study indicate that motivation has a positive and significant effect on employee performance, training and development have a positive and significant effect on employee performance, while simultaneously motivation, training and development together have a positive effect on employee performance at PT. Subang Autocomp Indonesia. Training and development have a dominant influence on employee performance. The coefficient of determination (Adjusted $R$ Square) is 0.416, which means that $41.6 \%$ of performance variables can be explained by motivation, training and development, while $58.4 \%$ can be explained by other variables which the researchers did not examine in this study.
\end{abstract}

Keywords: motivation, training and development, performance.

\section{Abstrak}

Tujuan penelitian ini adalah untuk menganalisis pengaruh motivasi, pelatihan dan pengembangan terhadap kinerja karyawan pada level operator PT. Subang Autocomp Indonesia. Jenis penelitian ini bersifat asosiatif kausal. Populasi penelitian ini adalah seluruh karyawan pada level operator di PT. Subang Autocomp Indonesia sebanyak 111 karyawan dan sebanyak 87 orang dijadikan sampel. Metode pengumpulan data penelitian ini adalah kuesioner, wawancara dan dokumentasi. Metode analisis data menggunakan analisis deskriptif dan regresi linier berganda. Hasil penelitian ini menunjukkan bahwa motivasi berpengaruh positif dan signifikan terhadap kinerja karyawan, pelatihan dan pengembangan memiliki pengaruh positif dan signifikan terhadap kinerja karyawan, sedangkan secara simultan motivasi, pelatihan dan pengembangan secara bersama-sama berpengaruh positif terhadap kinerja karyawan PT. Subang Autocomp Indonesia. Pelatihan dan pengembangan memiliki pengaruh dominan terhadap kinerja karyawan. Koefisien determinasi (Adjusted $R$ Square) adalah 0,416 artinya bahwa 41,6\% variabel kinerja dapat dijelaskan dari motivasi, 
pelatihan dan pengembangan sedangkan sebanyak 58,4\% dapat dijelaskan oleh variabel lain dimana tidak diteliti oleh peneliti dalam penelitian ini.

Kata kunci: motivasi, pelatihan dan pengembangan, kinerja

\section{Coresponden Author}

Email: 1910632020023@student.unsika.ac.id Artikel dengan akses terbuka dibawah lisensi

\section{Pendahuluan}

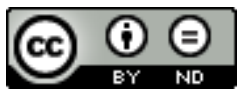

Kinerja individu karyawan sangat memengaruhi keberhasilan suatu organisasi atau perusahaan. Setiap organisasi selalu berupaya meningkatkan kinerja setiap karyawannya agar tujuan organisasi tersebut tercapai. Sampai saat ini pihak manajemen masih menghadapi masalah dalam meningkatkan kinerja karyawannya, sehingga pihak manajemen dituntut untuk memahami faktor-faktor apa saja yang dapat memengaruhi kinerja karyawannya baik itu faktor positif maupun negatif.

Masuknya era globalisasi merupakan sebuah persaingan yang sangat ketat saat ini, setiap organisasi terutama perusahaan harus mempunyai aset-aset yang unggul dan melestarikannya agar mampu menghadapi persaingan tersebut. Salah satu aset penting yang menjadi perhatian adalah sumber daya manusia. Selain menjadi sumber daya, manusia merupakan aset yang unik, karena satu-satunya aset yang bernyawa, sehingga perlu diberi treatment khusus agar loyalitasnya terhadap perusahaan terjaga. Sebagai satu-satunya sumber daya yang memiliki perasaan, keinginan, keterampilan, pengetahuan, dorongan, daya dan karya maka perusahaan perlu mendidik, melatih, menjaga dan mengoptimalkan potensi yang dimiliki oleh individu tersebut agar tercapainya tujuan perusahaan (Sutrisno, 2014).

Sumber daya manusia yang berkualitas menjadi sebuah keharusan yang dicari oleh perusahaan agar dapat bersaing di era globalisasi saat ini. Perusahaan diharuskan memperoleh, melatih, mengembangkan dan mempertahankan sumber daya manusia yang berkualitas. Sumber daya manusia yang berkualitas akan dapat menghasilkan pekerjaan yang maksimal dan efisien. Semakin tinggi tingkat kualitas sumber daya manusia, maka semakin tinggi pula tingkat kinerja karyawan dalam menyelesaikan tugasnya. Hal tersebut akan mendorong peningkatan efektivitas dan efisiensi pekerjaan yang dihasilkan oleh sumber daya manusia (Agusta, 2013).

Kedudukan karyawan di sebuah perusahaan mempunyai andil yang sangat besar dalam menentukan keberhasilan perusahaan tersebut. Keberhasilan suatu perusahaan dapat terwujud jika perusahaan memiliki sumber daya manusia yang konsisten, bersih, bertanggung jawab, berorientasi ke masa depan dan memiliki sikap profesionalisme dalam melaksanakan tanggung jawabnya.

Salah satu instrumen yang dapat digunakan untuk meningkatkan kualitas sumber daya manusia di perusahaan adalah pemberian program pelatihan dan pengembangan. Pelatihan adalah rangkaian kegiatan yang diberikan kepada suatu individu atau kelompok 
yang bertujuan untuk meningkatkan keahlian dan pengetahuan agar professional di bidangnya (Widodo, 2015). Sedangkan pengembangan merupakan sebuah proses pendidikan baik formal maupun non formal yang dilakukan secara sadar, terencana, terarah, teratur dan bertanggung jawab dalam memperkenalkan, menumbuhkan, membimbing, mengembangkan suatu dasar pribadi yang seimbang dan utuh serta selaras antara pengetahuan, keterampilan dan bakat agar tercapainya kemampuan optimal dari individu tersebut (dalam Afrilianasari, 2014). Secara singkat pelatihan dan pengembangan merupakan suatu rangkaian kegiatan yang bertujuan untuk meningkatkan kinerja baik untuk saat ini maupun di masa mendatang (Zainal, Ramly, Mutis, \& Arafah, 2019).

PT. Subang Autocomp Indonesia (SUAI) adalah salah satu perusahaan manufaktur yang ada di kabupaten Subang yang memproduksi komponen otomotif dengan produk utamanya adalah wiring harness, yaitu salah satu komponen kendaraan bermotor yang merupakan serangkaian kabel dengan fungsi dan jenis yang bemacam-macam seperti untuk air bag, body front harness, door harness, engine harness dll. Komponen ini merupakan bagian vital dalam kendaraan yang berfungsi seperti sistem syaraf pada manusia. Fungsi wiring harness adalah menyalurkan perintah kelistrikan pada kendaraan sehingga alur listrik dapat tersalur dari satu bagian ke bagian yang lain. Komponen rangkaian kabel ini sangat penting dan menentukan performa maupun keselamatan bagi pengguna kendaraan.

Kuantitas dan kualitas pelaksanaan kegiatan pelatihan yang tidak mencukupi serta kurangnya pemberian motivasi yang baik akan berdampak pada hasil kinerja karyawan yang cenderung menurun dikarenakan karyawan banyak melakukan kesalahan. Keadaan ini merupakan fokus utama pagi perusahaan untuk dibenahi, khususnya di bidang produksi wiring harness sebagai komponen utama bagi kendaraan (Hasibuan, 2015).

Pentingnya kualitas kinerja karyawan dalam mencapai target perusahaan khususnya di bidang manufaktur, mendorong pihak manajemen agar selalu memberikan pembinaan, pelatihan dan pengembangan sumber daya manusia yang ada di perusahaan melalui program pelatihan dan pengembangan serta motivasi kerja bagi seluruh karyawan yang menjadi aset utama bagi perusahaan.

Dari hasil wawancara langsung dan meminta data sekunder perusahaan kepada kepala personalia mengungkapkan bahwa kinerja karyawan masih belum optimal dan cenderung menurun. Berikut adalah tabel capaian kinerja PT. Subang Autocomp Indonesia (SUAI) dalam kurun waktu 4 tahun:

\section{Tabel 1}

Capaian Kinerja PT. Subang Autocomp Indonesia 2017-2020 Kinerja PT. Subang Autocomp Indonesia

\begin{tabular}{cccc}
\hline No & Tahun & Target & Capaian \\
\hline 1 & 2017 & $100 \%$ & $88 \%$ \\
\hline 2 & 2018 & $100 \%$ & $80 \%$ \\
\hline 3 & 2019 & $100 \%$ & $74 \%$ \\
\hline 4 & 2020 & $100 \%$ & $67 \%$ \\
\hline
\end{tabular}


Sumber: PT. Subang Autocomp Indonesia

Berdasarkan dari tabel 1 data capaian kinerja PT. Subang Autocomp Indonesia (SUAI) menunjukkan penurunan kinerja dari tahun 2017 ke tahun 2020, target perusahaan tidak pernah tercapai, hal ini menunjukkan perusahaan tersebut mempunyai permasalahan khususnya dalam kinerja karyawannya yang tidak optimal.

Didapati juga hasil wawancara dengan beberapa pegawai mengindikasikan adanya ketidakseriusan pegawai dalam mengikuti pelatihan dan pengembangan yang diberikan, banyaknya pegawai yang tidak mengikuti pelatihan, kurangnya daya kritis dan berfikir visioner. Hal inilah yang menjadi asumsi bahwa pegawai kurang termotivasi, sehingga tidak semua peserta mengikuti pelatihan dan menurunnya presentase Indikator Kinerja.

Sebagai perusahaan yang harus memenuhi kebutuhan pelanggannya, perusahaan dituntut untuk selalu meningkatkan kinerja karyawannya. Karena dengan adanya kinerja yang baik dalam diri setiap karyawan, maka mengoptimalkan kemampuannya untuk melakukan pekerjaan yang sudah diberikan.

Adapun informasi mengenai beberapa masalah yang terjadi di PT. Subang Autocomp Indonesia, yakni:

\section{Tabel 2}

Hambatan Pelatihan pada PT. Subang Autocomp Indonesia

\begin{tabular}{clc}
\hline No & \multicolumn{1}{c}{ Hambatan } & Persentase \\
\hline 1. & $\begin{array}{l}\text { Jadwal pelaksanaan kegiatan pelatihan yang telah } \\
\text { dibuat bisa tiba-tiba berubah, dari segi waktu } \\
\text { maupun tempat pelaksanaan kegiatan pelatihan. }\end{array}$ & $25 \%$ \\
\hline 2. & $\begin{array}{l}\text { Peserta yang tidak tanpa alasan yang jelas/tanpa } \\
\text { keterangan. }\end{array}$ & $35 \%$ \\
\hline
\end{tabular}

Sumber: PT. Subang Autocomp Indonesia

Tabel 3

Hambatan Motivasi pada PT. Subang Autocomp Indonesia

\begin{tabular}{clc}
\hline No & \multicolumn{1}{c}{ Hambatan } & Persentase \\
\hline 1. & Karyawan yang memaksakan diri. & $10 \%$ \\
\hline 2. & Karyawan yang tidak dapat bersosialisasi & $20 \%$ \\
\hline 3. & Karyawan yang tidak dapat menghadapi tekanan & $25 \%$ \\
\hline \multicolumn{3}{c}{ Sumber: PT. Subang Autocomp Indonesia }
\end{tabular}

Tabel 4

Hambatan Kinerja pada PT. Subang Autocomp Indonesia

\begin{tabular}{clc}
\hline No & \multicolumn{1}{c}{ Hambatan } & Persentase \\
\hline 1. & Karyawan yang tidak dapat bersikap professional & $30 \%$ \\
\hline 2. & Karyawan yang kurang disiplin & $20 \%$ \\
\hline
\end{tabular}

Sumber: PT. Subang Autocomp Indonesia

(Rivai \& Junani Sagala, 2011) menuturkan bahwa pelatihan merupakan proses sistematis yang dapat mengubah tingkah laku pegawai agar tujuan organisasi tercapai. 
Pekerjaan dapat dikatakan berhasil jika kemampuan pegawainya telah melewati proses pelatihan dan pengembangan yang telah dibuat sesuai kebutuhan perusahaan tersebut.

Motivasi menurut (Mangkunegara, 2016) adalah kondisi atau keadaan yang membuat pegawai tergerak untuk mencapai tujuannya. Dengan adanya motivasi yang kuat dari dalam diri pegawai, maka dapat mengarahkan daya dan potensi pegawai tersebut untuk dapat bekerja sama serta berhasil mewujudkan tujuan yang telah ditentukan.

(Hasibuan, 2015) menjelaskan bahwa kinerja merupakan hasil dari beban tugas yang telah dilaksanakan pegawai berdasarkan kecakapan, pengalaman, kesungguhan dan waktu. Apabila pelatihan dan pengembangan sudah dilaksanakan sesuai dengan waktu yang telah ditentukan oleh perusahaan, maka diharapkan para pegawai memperoleh kompetensi dan motivasi kerja yang dibutuhkan perusahaan, serta atasan dapat terus memantau dan meningkatkan kinerja karyawan secara maksimal.

(Setiawan, 2015) melakukan penelitian yang berjudul "Pengaruh Motivasi Kerja Terhadap Kinerja Karyawan Level Pelaksana Di Divisi Operasi PT. Pusri Pelambang”, penelitian tersebut bertujan untuk mengetahui pengaruh Motivasi Kerja (X) terhadap Kinerja Karyawan (Y) di divisi operasi PT. Pusri Palembang. Dengan hipotesis Motivasi Kerja mempunyai pengaruh yang signifikan terhadap Kinerja Karyawan di divisi operasi PT. Pusri Palembang. Teknik sampling yang digunakan adalah Proporsional Random Sampling. Sampel penelitian sebanyak 250 karyawan level pelaksana. Pengolahan data menggunakan Analisis Jalur (Path Analysis). Hasil penelitian menunjukkan bahwa motivasi kerja berpengaruh signifikan terhadap kinerja karyawan level pelaksana di Divisi Operasi PT. Pusri Palembang. Dengan besarnya koefisien jalur motivasi kerja terhadap kinerja adalah 0,517 . Hal ini berarti setiap peningkatan motivasi sebesar satu satuan, maka akan meningkatkan kinerja sebesar 0,517. Pengujian dengan t statisik menunjukkan bahwa nilai $t_{\text {hitung }}(11,257)>t_{\text {tabel }}(1,970)$. Hal tersebut mengindikasikan penolakan Ho yang menunjukkan bahwa motivasi kerja berpengaruh secara signifikan terhadap kinerja karyawan level pelaksana di Divisi Operasi PT. Pusri Palembang. Besarnya pengaruh motivasi kerja secara langsung terhadap kinerja adalah sebesar $26,68 \%$ sedangkan sisanya sebesar 73,32\% dipengaruhi oleh faktor lain di luar kontribusi penelitian ini.

(Daniati, 2019) melakukan penelitian yang berjudul "Pengaruh Pelatihan dan Pengembangan SDM Terhadap Kinerja Pegawai Dinas Pekerjaan Umum dan Penataan Ruang Kabupaten Merangin", penelitian tersebut bertujuan untuk mengetahui pengaruh Pelatihan $\left(\mathrm{X}_{1}\right)$ dan Pengembangan $\left(\mathrm{X}_{2}\right)$ SDM terhadap Kinerja pegawai (Y) di Dinas Pekerjaan Umum dan Penataan Ruang Kabupaten Merangin. Dengan hipotesis Pelatihan dan Pengembangan mempunyai pengaruh yang signifikan terhadap Kinerja pegawai di Dinas Pekerjaan Umum dan Penataan Ruang Kabupaten Merangin. Penelitian ini dilakukan dengan metode kuantitatif, jenis penelitian metode korelasi. Subjek penelitian adalah kantor Dinas Pekerjaan Umum dan Penataan Ruang Kabupaten Merangin dengan jumlah populasi 118 orang dari semua pegawai PNS. Penetapan sampel dengan menggunakan teknik stratified random sampling sebanyak 91 orang responden. Pengumpulan data dilakukan dengan observasi, dokumentasi dan angket. Pengolahan 
data menggunakan Analisis Jalur (Path Analysis). Hasil penelitian menunjukkan bahwa pelatihan dan pengembangan berpengaruh signifikan terhadap kinerja pegawai di Dinas Pekerjaan Umum dan Penataan Ruang Kabupaten Merangin. Hal ini dibuktikan dengan hasil perhitungan antara variabel pelatihan terhadap kinerja bahwa nilai thitung $(4,275)>$ $t_{\text {tabel }}(1,661)$ dan antara variabel pengembangan terhadap kinerja dengan nilai thitung $(1,686)>t_{\text {tabel }}(1,661)$ sesuai dengan pengujian hipotesis bahwa jika nilai $t_{\text {hitung }}>t_{\text {tabel }}$ maka pengujian hipotesis Ho ditolak, dan nilai korelasi berganda sebesar $(0,187)$, kemudian hasil uji $\mathrm{F}$ bahwa nilai $F_{\text {hitung }}(11,354)>F_{\text {tabel }}(3,10)$ sesuai dengan pengujian hipotesis Ho ditolak. Dengan demikian menandakan variabel pelatihan dan pengembangan secara simultan berpengaruh signifikan terhadap variabel kinerja. Didapatkan hasil koefisien determinasi dari pengaruh pelatihan dan pengembangan terhadap kinerja sebesar $18,7 \%$ sedangkan sisanya $81,3 \%$ dipengaruhi oleh faktor lain di luar kontribusi penelitian ini.

Atas dasar kaitan dari penelitian terdahulu maka peneliti ingin menganalisa hubungan yang terjadi antara motivasi, pelatihan dan pengembangan, serta kinerja pegawai yang ada di PT. Subang Autocomp Indonesia khusunya pada level Operator. Adapun tujuan penelitian ini adalah untuk mengetahui:

1) Pengaruh motivasi terhadap kinerja karyawan pada level Operator di PT. Subang Autocomp Indonesia.

2) Pengaruh pelatihan dan pengembangan terhadap kinerja karyawan pada level Operator di PT. Subang Autocomp Indonesia.

3) Pengaruh motivasi, pelatihan dan pengembangan terhadap kinerja pegawai pada level Operator di PT. Subang Autocomp Indonesia.

Dengan dilakukannya penelitian ini, diharapkan peneliti dapat memecahkan permasalahan di masa yang akan datang yang berkaitan dengan judul penelitian. Serta menambah wawasan dan bahan referensi peneliti lain dengan judul Motivasi, Pelatihan dan Pengembangan serta kinerja. Bagi perusahaan sendiri diharapkan menjadi bahan informasi dan pertimbangan pihak manajemen perusahaan PT. Subang Autocomp Indonesia dalam meningkatkan kinerja karyawan khususnya pada level Operator.

\section{Metode Penelitian}

Penelitian ini dilakukan pada PT. Subang Autocomp Indonesia yang terletak di Jl. Raya Subang KM. 22, RT 09 / RW 03 Wantilan Cipeundeuy, Subang, Jawa Barat. Penelitian ini dilakukan pada Oktober 2020 sampai November 2020 dengan tahapan penelitian meliputi (1) Prasurvai, (2) Uji Coba Instrumen (3) Pengumpulan Data, (4) Analisis Data, dan (5) Penulisan laporan.

Populasi yang digunakan dalam penelitian ini adalah seluruh pegawai pada level Operator yang ada di PT. Subang Autocomp Indonesia. Populasi penelitian berjumlah 111 orang. Teknik pengambilan sampel yang digunakan dalam penelitian ini adalah simple random sampling dengan menggunakan rumus Slovin, yaitu:

$$
\frac{N}{1+\left(N x e^{2}\right)}
$$


Dimana: $\mathrm{n}=$ ukuran sampel

$\mathrm{N}=$ populasi

$\mathrm{e}=$ perkiraan tingkat kesalahan $(5 \%)$

Maka jumlah sampel yang diambil yaitu:

$n=\frac{111}{1+\left(111 \times 0.05^{2}\right)}$

$n=86,88$

Sehingga penelitian ini menggunakan sampel sebanyak 87 orang. Peneliti megumpulkan data menggunakan 2 (dua) cara, yaitu dengan menyebarkan kuesioner kepada 87 responden yang telah disusun.

Instrumen penelitian yang digunakan merupakan instrumen yang dikembangkan oleh peneliti sendiri. Peneliti menggunakan skala Likert untuk mengetahui masingmasing variabel yaitu variabel $\mathrm{X}_{1}$ (Motivasi), $\mathrm{X}_{2}$ (Pelatihan dan Pengembangan dan variabel Y (kinerja karyawan). Model hubungan antara ketiga variabel penelitian ini dapat digambarkan sebagai berikut:

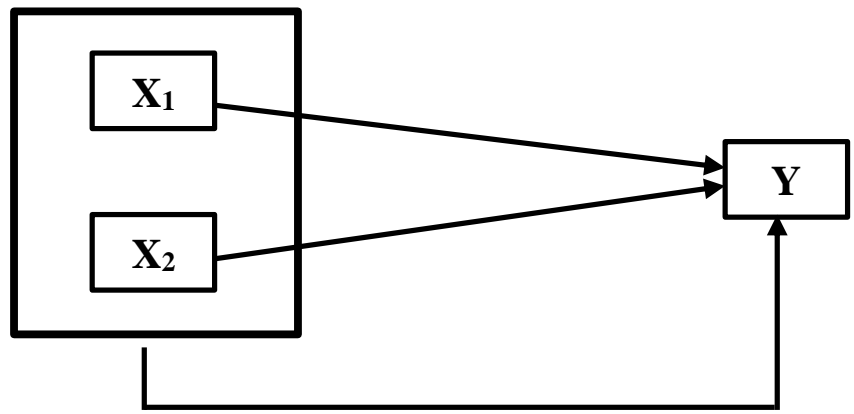

Gambar 1

Alur Hubungan Antar Variabel Penelitian

Keterangan:

$\mathrm{X} 1$ = Motivasi

$\mathrm{X} 2$ = Pelatihan dan Pengembangan

$\mathrm{Y}=$ Kinerja

Menurut (Sugiyono, 2017) menuturkan bahwa skala likert digunakan untuk mengukur sikap, pendapat dan persepsi individu/kelompok tentang fenomena sosial. Dalam analisis kuantitatif penelitian ini, maka setiap pertanyaan diberi skala sangat setuju sampai sangat tidak setuju. Skala likert menggunakan 5 (lima) tingkatan jawaban yang dapat dilihat dari tabel berikut: 
Tabel 5

Instrumen Skala Likert

\begin{tabular}{clc}
\hline No & \multicolumn{1}{c}{ Pertanyaan } & Skor \\
\hline 1 & Sangat Setuju (SS) & 5 \\
\hline 2 & Setuju (S) & 4 \\
\hline 3 & Kurang Setuju (KS) & 3 \\
\hline 4 & Tidak Setuju (TS) & 2 \\
\hline 5 & Sangat Tidak Setuju (STS) & 1 \\
\hline \multicolumn{3}{c}{ Sumber: (Sugiyono, 2017) } \\
\end{tabular}

Cara selanjutnya yaitu studi kepustakaan, serta dokumen-dokumen yang diperoleh di lokasi penelitian. Data yang telah diperoleh kemudian dikumpulkan, selanjutnya peneliti melakukan uji instrumen. Uji instrumen melalui 2 tahap pengujian yaitu, uji validitas dan uji realibilitas. Untuk melakukan uji validitas, peneliti menggunakan rumus korelasi Product Moment Pearson. Sedangkan uji realibilitas, peneliti menggunakan rumus Alpha Cronbach sebagai alat ukur. Adapun intrepretasi koefisien Korelasi $r$ sebagai berikut (Sugiyono, 2016):

Tabel 6

Intrepretasi Koefisien Korelasi $\mathbf{r}$

\begin{tabular}{cc}
\hline Interval Koefisien & Tingkat Hubungan \\
\hline $0,80-1,00$ & Sangat Kuat \\
\hline $0,60-0,80$ & Kuat \\
\hline $0,40-0,59$ & Cukup Kuat \\
\hline $0,20-0,39$ & Rendah \\
\hline $0,00-0,19$ & Sangat Rendah \\
\hline
\end{tabular}

Pengujian selanjutnya adalah melakukan uji hipotesis atau uji statistik t yang bertujuan agar peneliti mengetahui seberapa besar pengaruh dari variabel independen secara individual dalam menjelaskan variasi variabel dependen dan dilanjutkan dengan melakukan uji parameter secara simultan atau uji F. 


\section{Hasil dan Pembahasan}

\section{A. Uji t variabel Motivasi, Variabel Pelatihan dan Pengembangan terhadap variabel Kinerja}

Hasil uji t penelitian ini dapat dilihat pada tabel 7 berikut.

\section{Tabel 7}

Hasil perhitungan uji t kedua variabel independent

\begin{tabular}{|c|c|c|c|c|c|c|}
\hline \multirow{2}{*}{\multicolumn{2}{|c|}{ Model }} & \multicolumn{2}{|c|}{$\begin{array}{l}\text { Unstandardized } \\
\text { Coefficients }\end{array}$} & \multirow{2}{*}{$\begin{array}{c}\text { Standardized } \\
\text { Coefficients } \\
\text { Beta }\end{array}$} & \multirow[b]{2}{*}{$\mathrm{t}$} & \multirow[b]{2}{*}{ Sig. } \\
\hline & & $\mathrm{B}$ & Std. Error & & & \\
\hline \multirow[t]{3}{*}{1} & (Constant) & 7.578 & 3.795 & & 1.997 & .049 \\
\hline & Motivasi & .462 & .142 & .315 & 3.245 & .002 \\
\hline & $\begin{array}{l}\text { Pelatihan Dan } \\
\text { Pengembangan }\end{array}$ & .317 & .072 & .425 & 4.380 & .000 \\
\hline
\end{tabular}

Sumber: Hasil olah data menggunakan SPSS 26.0

Dari tabel 7 di atas dapat dijabarkan sebagai berikut:

1) Dari hasil uji t menggunakan SPSS didapatkan nilai thitung untuk variabel Motivasi (X1) terhadap variabel Kinerja (Y) sebesar 3,245 dan $t_{\text {tabel }}$ sebesar 1,66320. Maka 3,245 > 1,66320 sehingga dapat disimpulkan bahwa variabel Motivasi (X1) mempunyai pengaruh yang positif dan signifikan terhadap variabel Kinerja (Y).

2) Dari hasil uji t menggunakan SPSS didapatkan nilai thitung untuk variabel Pelatihan dan Pengembangan (X2) terhadap variabel Kinerja (Y) sebesar 4,380 dan $t_{\text {tabel }}$ sebesar 1,66320. Maka 4,380 > 1,66320 sehingga dapat disimpulkan bahwa variabel Pelatihan dan Pengembangan (X2) mempunyai pengaruh yang positif dan signifikan terhadap variabel Kinerja (Y).

\section{B. Uji F antara variabel Motivasi, Pelatihan dan Pengembangan secara simultan terhadap variabel Kinerja}

Hasil uji F penelitian ini dapat dilihat pada tabel 7 sebagai berikut.

\section{Tabel 8}

\begin{tabular}{|c|c|c|c|c|c|c|}
\hline \multicolumn{7}{|c|}{ Uji Simultan (Uji F) ANOVA ${ }^{a}$} \\
\hline \multirow[b]{2}{*}{ Model } & & Sum of & & Mean & & \\
\hline & & Squares & df & Square & $\mathrm{F}$ & Sig. \\
\hline \multirow[t]{3}{*}{1} & Regression & 687.129 & 2 & 343.565 & 29.867 & $.000^{\mathrm{b}}$ \\
\hline & Residual & 966.250 & 84 & 11.503 & & \\
\hline & Total & 1653.379 & 86 & & & \\
\hline
\end{tabular}

a. Dependent Variable: Kinerja

b. Predictors: (Constant), Pelatihan Dan Pengembangan,

Motivasi

Dari tabel 8 diketahui bahwa $F_{\text {hitung }}$ adalah 29,867. Nilai $F_{\text {tabel }}$ dengan sampel sebanyak 87 dan dua variabel bebas adalah 3,11. Perbandingan antara $F_{\text {tabel }}$ dan $F_{\text {hitung }}$ adalah $29,867>3,11$, maka dapat disimpulkan terdapat pengaruh yang positif dan 
signifikan antara variabel Motivasi (X1) dan Pelatihan dan Pengembangan (X2) secara bersama-sama atau simultan terhadap variabel Kinerja (Y).

\section{Koefisien Determinasi}

Nilai koefisien determinasi penelitian dapat dilihat pada tabel berikut ini.

\section{Tabel 9}

Koefisien Determinasi

\begin{tabular}{ll|r|r|r}
\hline $\begin{array}{l}\text { Mod } \\
\text { el }\end{array}$ & $\mathrm{R}$ & $\begin{array}{c}\mathrm{R} \\
\text { Square }\end{array}$ & $\begin{array}{c}\text { Adjusted } \\
\text { R Square }\end{array}$ & $\begin{array}{c}\text { Std. Error } \\
\text { of the } \\
\text { Estimate }\end{array}$ \\
\hline 1 & $.645^{\mathrm{a}}$ & .416 & .402 & 3.392 \\
\hline
\end{tabular}

a. Predictors: (Constant), Pelatihan Dan

Pengembangan, Motivasi

b. Dependent Variable: Kinerja

Berdasarkan tabel 9 Koefisien Determinasi didapatkan nilai R Square sebesar 0,416 yang artinya variabel Motivasi dan Variabel Pelatihan dan Pengembangan secara bersama-sama mampu menjelaskan variabel Kinerja sebesar 41,6\% sedangkan, sisanya sebesar 58,4\% merupakan faktor-faktor lain yang tidak diteliti dalam penelitian ini.

\section{Analisis Regresi Linear Berganda}

Berdasarkan tabel 6 didapatkan persamaan regresi linear berganda sebagai berikut. $\mathrm{Y}=7,578+0,462 \mathrm{X}_{1}+0,317 \mathrm{X}_{2}$.

Dimana:

$\mathrm{X}_{1}=$ Motivasi

$\mathrm{X}_{2}=$ Pelatihan dan Pengembangan

$\mathrm{Y}=$ Kinerja

Penjelasan sebagai berikut.

1) Nilai konstanta (koefisien intersep) yang diperoleh dari tabel 7 adalah sebesar 7,578. Hal ini menyatakan jika variabel Motivasi $\left(\mathrm{X}_{1}\right)$ dan variabel Pelatihan dan Pengembangan $\left(\mathrm{X}_{2}\right)$ nol maka nilai variabel Kinerja $(\mathrm{Y})$ sebesar 7,578.

2) Nilai koefisien regresi variabel Motivasi $\left(X_{1}\right)$ terhadap variabel Kinerja $(Y)$ adalah sebesar 0,462. Hal ini menjelaskan jika variabel Motivasi $\left(\mathrm{X}_{1}\right)$ naik sebesar $1 \%$, akan meningkatkan variabel Kinerja (Y) sebesar 0,462, dengan asumsi variabel Pelatihan dan Pengembangan $\left(\mathrm{X}_{2}\right)$ dan konstanta dianggap tetap. Hal ini mengartikan semakin baik dan meningkatnya motivasi setiap karyawan maka akan semakin meningkat pula kinerja karyawan tersebut. Berdasarkan hasil jawaban dari 87 responden yang diperoleh dari angket menunjukkan bahwa motivasi berada pada skala baik. Hal ini selaras dengan (Akhyadi, 2015) yang berpendapat bahwa motivasi mampu meningkatkan kinerja seseorang, baik itu produktivitas, kedisiplinan, kreativitas, rasa tanggung jawab bahkan kepuasan keryawan tersebut. Penelitian ini sejalan dengan penelitian yang dilakukan oleh (Arfan Aruan, 2013) berjudul Pengaruh Pelatihan Kerja dan Motivasi Terhadap 
Kinerja Karyawan PT. Sucofindo (Persero) Surabaya. Dalam penelitiannya menyebutkan bahwa variabel motivasi berpengaruh paling dominan terhadap kinerja dengan besar pengaruhnya adalah 37,21\%. Sedangkan untuk variabel pelatihan terhadap kinerja mempunyai pengaruh sebesar 23,72\%. (Mitchell, 1978) mengungkapkan bahwa kinerja merupakan keterikatan antara kemampuan dan motivasi. Dalam jurnal yang ditulis oleh (Kusuma, 2015) mennyimpulkan bahwa motivasi merupakan kunci utama dalam meningkatkan kinerja karyawan. Hal tersebut bertujuan agar karyawan bersemangat untu menyelesaikan beban tugas yang diberikan kepadanya.

3) Nilai koefisien regresi variabel Pelatihan dan Pengembangan $\left(X_{2}\right)$ terhadap variabel Kinerja (Y) adalah sebesar 0,317. Hal ini menjelaskan jika variabel $\left(\mathrm{X}_{2}\right)$ naik sebesar 1 persen, maka hal tersebut akan meningkatkan variabel Kinerja (Y) sebesar 0,317 persen, dengan asumsi bahwa variabel Motivasi $\left(\mathrm{X}_{1}\right)$ dianggap konstan atau tidak berubah. Hasil ini sesuai dengan jawaban yang diberikan oleh 87 responden pada variabel pelatihan dan pengembangan berada pada skala baik. Penelitian yang dilakukan oleh (Lolowang, Adolfina, \& Lumintang, 2016) menyimpulkan bahwa pelatihan dan pengembangan merupakan proses meningkatkan pengetahuan dan keterampilan karyawan. Serta mengubah sikap karyawan menjadi lebih efektif dalam melakukan pekerjaannya. Kinerja yang baik dipengaruhi oleh peningkatan pengetahuan dan keterampilan yang didapat oleh karyawan melalui kegiatan pelatihan dan pengembangan yang diberikan oleh perusahaannya. Secara singkat (Rivai \& Junani Sagala, 2011) menuturkan bahwa pelatihan merupakan kegiatan untuk meningkatkan kinerja baik untuk saat ini maupun untuk masa medatang. Sedangkan pengembangan diberikan agar membantu karyawan untuk lebih peduli terhadap tanggung jawab pekerjaannya. Selaras dengan penelitian yang dilakukan oleh (Kusuma, 2015) yang berjudul Pengaruh Motivasi dan Pelatihan Terhadap Kinerja Studi pada Karyawan PT. PLN (Persero) Distribusi Jawa Timur Area Malang. Dalam penelitian tersebut menunjukkan adanya pengaruh signifikan secara simultan antara variabel pelatihan dan variabel motivasi terhadap variabel kinerja karyawan.

\section{Kesimpulan}

Berdasarkan hasil penelitian menunjukkan adanya pengaruh positif dan signifikan antara Motivasi terhadap kinerja karyawan di PT. Subang Autocomp Indonesia. Semakin tinggi tingkat motivasi seorang karyawan maka akan semakin tinggi pula tingkat kinerja karyawan tersebut. Hal ini akan berdampak baik pada perusahaan.

Hal yang sama juga terjadi pada variabel pelatihan dan pengembangan terhadap variabel kinerja. Semakin baik suatu pelatihan dan pengembangan yang diberikan perusahaan terhadap keryawan maka akan semakin tinggi pula tingkat kinerja karyawan tersebut. Hal tersebut tentu akan berpengaruh positif bagi perusahaan.

Berdasarkan hasil dari perhitungan regresi linier berganda menunjukkan bahwa motivasi lebih dominan pengaruhnya terhadap kinerja karyawan. Sehingga perusahaan 
sebaiknya lebih memberikan perhatian lebih kepada karyawannya. Baik dalam kebutuhan fisiologis, rasa aman, sosial, harga diri dan aktualisasi diri.

Bagi peneliti selanjutnya penulis menyarankan untuk mendalami faktor apa saja yang menyebabkan motivasi seorang pegawai rendah serta pengaruhnya terhadap kinerja pegawai. Dan juga faktor apa saja yang dapat memengaruhi pelatihan dan pengembangan dalam suatu perusahaan. 
Liandy Lumban Tobing, Edi Suswardji Nugroho dan Solehudin

\section{BIBLIOGRAFI}

Agusta, Leonando. (2013). Pengaruh pelatihan dan motivasi kerja terhadap kinerja karyawan CV Haragon Surabaya. Agora, 1(3), 1399-1408.

Akhyadi, Kaswan \&. Ade Sadikin. (2015). Pengembangan Sumber Daya Manusia. Bandung: Alfabeta.

Arfan Aruan, Daniel. (2013). Pengaruh pelatihan kerja dan motivasi terhadap kinerja karyawan PT. Sucofindo (persero) Surabaya. Jurnal Ilmu Manajemen (JIM), 1(2).

dalam Afrilianasari, Iskandar Wiryokusumo. (2014). Teori Pengembangan. Jakarta: Kencana.

Daniati, Rina. (2019). Pengaruh Pelatihan Dan Pengembangan Sdm Terhadap Kinerja Pegawai Dinas Pekerjaan Umum Dan Penataan Ruang Kabupaten Merangin. Ekopendia, 4(1), 117-127.

Hasibuan. (2015). Manajemen Sumber Daya Manusia. Bandung: Bumi Aksara.

Kusuma, Galih Candra. (2015). Pengaruh Motivasi dan Pelatihan Terhadap Kinerja (Studi pada Karyawan PT. PLN (Persero) Distribusi Jawa Timur Area Malang). Jurnal Administrasi Bisnis, 22(1).

Lolowang, Melvin Grady, Adolfina, A., \& Lumintang, Genita. (2016). Pengaruh Pelatihan dan Pengembangan Sumber Daya Manusia terhadap Kinerja Karyawan pada Pt. Berlian Kharisma Pasifik Manado. Jurnal EMBA: Jurnal Riset Ekonomi, Manajemen, Bisnis Dan Akuntansi, 4(2).

Mangkunegara, A. A. Anwar Prabu. (2016). Manajemen sumber daya manusia perusahaan. Bandung: PT. Remaja Rosdakarya.

Mitchell, Terence R. (1978). People in organizations: Understanding their behavior. Newyork: McGraw-Hill Companies.

Rivai, Veithzal, \& Junani Sagala, Ella. (2011). Manajemen sumber daya manusia perusahaan. Cetakan Pertama. Jakarta: PT. Raja Grafindo Persada.

Setiawan, Kiki Cahaya. (2015). Pengaruh motivasi kerja terhadap kinerja karyawan level pelaksana di divisi operasi PT. Pusri Palembang. Psikis: Jurnal Psikologi Islami, $1(2), 43-53$.

Sugiyono. (2016). Metode Penelitian Pendidikan. Bandung: Alfabeta.

Sugiyono. (2017). Metode Penelitian Pendidikan: Pendekatan Kuantitatif, Kualitatif, dan $R \& D$. Bandung: Alfabeta.

Sutrisno, Edy. (2014). Manajemen Sumber Daya Manusia, Cetakan Keenam. Jakarta: 
Pengaruh Motivasi, Pelatihan dan Pengembangan Terhadap Kinerja Karyawan

Pranada Media Group.

Widodo, Suparno Eko. (2015). Manajemen Pengembangan Sumber Daya Manusia. Yogyakarta: Pustaka Pelajar.

Zainal, Veithzal Rivai, Ramly, H. Mansyur, Mutis, Thoby, \& Arafah, Willy. (2019). Manajemen sumber daya manusia untuk perusahaan dari teori ke praktik. Jakarta: Rajawali 